\title{
83. Ancient Records of Sunspots and Auroras in the Far East and the Variation of the Period of Solar Activity.
}

By Sigeru KANDA.

Tokyo Astronomical Observatory.

(Comm. by K. Hirayama, M.I.A., July 12, 1933.)

Ancient records of sunspots in the Far East have been hitherto collected by the following persons:-

\begin{tabular}{|c|c|c|c|c|}
\hline Author & Epoch & $\begin{array}{l}\text { No. of } \\
\text { records }\end{array}$ & Origin & Published in \\
\hline Williams & 301-1205 & 45 & China & M.N. 23, 1873 \\
\hline Hirayama, $\mathrm{S}$. & $188-1638$ & 77 & , & Observatory $\mathbf{1 2}, 1889$ \\
\hline Moidrey & B.C. $28-1638$ & 79 & , & Bull. Astr. 21, 1904 \\
\hline Kanda, S. & B.C. $28-1743$ & 142 & $\begin{array}{l}\text { Japan, Korea } \\
\text { and China }\end{array}$ & $\begin{array}{l}\text { Tokyo Astr. Obs. } \\
\text { Report 1, } 1932\end{array}$ \\
\hline
\end{tabular}

In the last named the writer has shown the records in the original form.

The era and the number of the records in the respective countries are as follows :-

$\begin{array}{lcc} & \text { Epoch } & \text { Number of records } \\ \text { Japan } & 851 & 1 \\ \text { Korea } & 1151-1743 & 35 \\ \text { China } & \text { B.C. } 28-1639 & 112\end{array}$

The total number is 143 , instead of 148 , as there are 5 common ones recorded in Korea and China.

The oldest record of sunspot, in Ch'ien Han Shu, Wu Hsing Chih, 前漢書五行志, reads as under:-

"In the 1st year of the epoch Ho P'ing, 河平 (B.C. 28), the 3rd month, on the day I Wei, 乙未, the sun was yellow at rising, and a black spot, as big as a coin, was observed in the centre of the sun."

The records are of course of visual nature. It is well accepted that the observation of sunspots by naked eye is only possible at the time of, or around maximum of solar activity. Approximate epochs of the maxima can be thus deduced from the records of ancient observations of sunspots, and will be utilized in the research on the period of solar activity.

That in certain ages, the deduction of the years of maxima of 
sunspots is not feasible, owing to the elapse of one or two centuries without any record, will have to be noted. In view of supplementing this deficiency of the material, the writer thought it justified to examine similar records of the aurora which has a cognate relation with the sunspots. The following table shows the number of them, adopted by the writer:-

$\begin{array}{lrc} & \text { Epoch } & \text { Number of records } \\ \text { Japan } & 620-1928 & 19 \\ \text { Korea } & 478-1681 & 24 \\ \text { China } & \text { B.C. } 30-1675 & 53\end{array}$

The oldest record is that which is in Ch'ien Han Shu, $\mathrm{Ku}$ Chin $\mathrm{Chu}$, 前漢書古今注. It reads:-

"At the night of a certain day, 7th month, 3rd year of the epoch Chien Shin, 建始, in the reign of Ch'ieng $\mathrm{Ti}$, 成帝, an atmospheric phenomena, composed of blue, yellow and white streamers, more than 100 feet long, appeared illuminating the ground. It gave rise to a rumour that they are celestial crevices, or that they are cutlasses of the heaven."

As it is well known, the frequency of auroral apparition has an affiliated relation with the solar activity, and the fact that an auroral apparition was observed in the countries like Japan, Korea and China, situated in low latitudes, indicates that its apparition was world wide. So, as in the cases of large sunspots, it may be easily conjectured that the phenomena has occurred near a maximum epoch of solar activity. Auroral records in the Far East are very helpful and conducive in this respect.

In the three tables, shown herein, $O$ indicates the epoch of sunspot record in the 1st, the epoch of sunspot maximum determined by Zürich Observatory in the 2nd, and the epoch of auroral record in the last. In some cases where consecutive records exist, lasting for several years, the mean epoch has been taken as $\mathrm{O}$. $\mathrm{C}$ has been computed by the formula,

$$
1622.0+10.83 \mathrm{E} \text {. }
$$

The residuals $\mathrm{O}-\mathrm{C}$ are plotted in the accompanying figure. It will be seen that these plotted points lie near a sine curve, which is represented by the expression,

$$
6.5 \sin \left(4^{\circ} .0 \mathrm{E}+280^{\circ}\right)
$$


No. 7.] Ancient Records of Sunspots and Auroras in the Far East.

TABLE I. Sunspot Records.

\begin{tabular}{c|c|c||c|c|c||c|c|c}
\hline $\mathrm{O}$ & $\mathrm{E}$ & $\mathrm{O}-\mathrm{C}$ & $\mathrm{O}$ & $\mathrm{E}$ & $\mathrm{O}-\mathrm{C}$ & $\mathrm{O}$ & $\mathrm{E}$ & $\mathrm{O}-\mathrm{C}$ \\
\hline & & & $\mathrm{y}$ & & & & \\
\hline-27.7 & -153 & +7.3 & 840.0 & -72 & -2.2 & 1202.8 & -39 & +3.2 \\
+20.2 & -148 & +1.0 & 851.9 & -71 & -1.2 & 1239.0 & -36 & +6.9 \\
187.7 & -133 & +6.1 & 865.1 & -70 & +1.2 & 1258.7 & -34 & +4.9 \\
302.0 & -122 & +1.3 & 875.6 & -69 & +0.3 & 1277.4 & -32 & +2.0 \\
311.3 & -121 & -0.3 & 888.0 & -68 & +2.4 & 1356.3 & -25 & +5.1 \\
322.1 & -120 & -0.3 & 927.2 & -64 & -1.7 & 1362.0 & -24 & -0.1 \\
342.2 & -118 & -1.9 & 947.9 & -62 & -2.6 & 1372.5 & -23 & -0.4 \\
354.2 & -117 & -0.7 & 974.1 & -60 & +1.9 & 1383.2 & -22 & -0.5 \\
359.9 & -116 & -5.8 & 1078.2 & -51 & +8.5 & 1402.9 & -20 & -2.5 \\
372.6 & -115 & -4.0 & 1108.7 & -48 & +6.5 & 1520.1 & -9 & -4.4 \\
388.9 & -114 & +1.5 & 1120.5 & -47 & +7.5 & 1604.0 & -1 & -7.2 \\
398.4 & -113 & +0.2 & 1130.2 & -46 & +6.4 & 1617.6 & 0 & -4.4 \\
501.1 & -103 & -5.4 & 1137.7 & -45 & +3.1 & 1624.3 & +1 & -8.5 \\
511.8 & -102 & -5.5 & 1148.4 & -44 & +2.9 & 1639.1 & +2 & -4.6 \\
567.1 & -97 & -4.4 & 1160.5 & -43 & +4.2 & 1720.4 & +9 & +0.9 \\
579.1 & -96 & -3.2 & 1171.9 & -42 & +4.8 & 1726.8 & +10 & -3.5 \\
807.9 & -75 & -1.9 & 1185.3 & -41 & +7.3 & 1743.8 & +11 & +2.7 \\
830.0 & -73 & -1.4 & 1193.9 & -40 & +5.1 & & & \\
\hline
\end{tabular}

TABLE II. Zürich Determinations.

\begin{tabular}{c|c|c|c|c|c||c|c|c}
\hline $\mathrm{O}$ & $\mathrm{E}$ & $\mathrm{O}-\mathrm{C}$ & $\mathrm{O}$ & $\mathrm{E}$ & $\mathrm{O}-\mathrm{C}$ & $\mathrm{O}$ & $\mathrm{E}$ & $\mathrm{O}-\mathrm{C}$ \\
\hline & 0 & -6.5 & 1727.5 & +10 & -2.8 & 1837.2 & +20 & -1.4 \\
1615.5 & +1 & -6.8 & 1738.7 & +11 & -2.4 & 1848.1 & +21 & -1.3 \\
1626.0 & +2 & -4.2 & 1750.3 & +12 & -1.7 & 1860.1 & +22 & -0.2 \\
1639.5 & +2.5 & -13 & -1.3 & 1870.6 & +23 & -0.5 \\
1649.0 & +3 & -5.5 & 1761.5 & +13 & -1.3 \\
1660.0 & +4 & -5.3 & 1769.7 & +14 & -3.9 & 1883.9 & +24 & +2.0 \\
1675.0 & +5 & -1.2 & 1778.4 & +15 & -6.1 & 1894.1 & +25 & +1.4 \\
1685.0 & +6 & -2.0 & 1788.1 & +16 & -7.2 & 1906.4 & +26 & +2.8 \\
1693.0 & +7 & -4.8 & 1805.2 & +17 & -0.9 & 1917.6 & +27 & +3.2 \\
1705.5 & +8 & -3.1 & 1816.4 & +18 & -0.5 & 1928.4 & +28 & +3.2 \\
1718.2 & +9 & -1.3 & 1829.9 & +19 & +2.1 & & & \\
\hline
\end{tabular}

TABLE III. Auroral Records.

\begin{tabular}{|c|c|c|c|c|c|c|c|c|}
\hline $\mathrm{O}$ & $\mathrm{E}$ & $\mathrm{O}-\mathrm{C}$ & $\mathrm{O}$ & $\mathrm{E}$ & $\mathrm{O}-\mathrm{C}$ & $\mathrm{O}$ & $\mathrm{E}$ & $\mathrm{O}-\mathrm{C}$ \\
\hline $\begin{array}{r}-29.4 \\
104.5 \\
173.7 \\
195.9 \\
306.0\end{array}$ & $\begin{array}{l}-153 \\
-141 \\
-134 \\
-132 \\
-122\end{array}$ & $\begin{array}{r}\mathrm{y} \\
+5.6 \\
+9.5 \\
+2.9 \\
+3.5 \\
+5.3\end{array}$ & $\begin{array}{r}987.5 \\
1018.0 \\
1032.9 \\
1073.0 \\
1088.6\end{array}$ & $\begin{array}{l}-59 \\
-56 \\
-55 \\
-51 \\
-50\end{array}$ & $\begin{array}{r}\mathrm{y} \\
+4.5 \\
+2.5 \\
+6.6 \\
+3.3 \\
+8.1\end{array}$ & $\begin{array}{l}1247.6 \\
1261.1 \\
1288.9 \\
1355.0 \\
1363.3\end{array}$ & $\begin{array}{l}-35 \\
-34 \\
-31 \\
-25 \\
-24\end{array}$ & $\begin{array}{r}\mathrm{y} \\
+4.7 \\
+7.3 \\
+2.6 \\
+3.8 \\
+1.2\end{array}$ \\
\hline $\begin{array}{l}313.9 \\
478.2 \\
492.8 \\
522.8 \\
568.5\end{array}$ & $\begin{array}{r}-121 \\
-105 \\
-104 \\
-101 \\
-97\end{array}$ & $\begin{array}{l}+2.3 \\
-6.7 \\
-2.9 \\
-5.4 \\
-3.0\end{array}$ & $\begin{array}{l}1100.4 \\
1117.1 \\
1129.2 \\
1140.0 \\
1150.7\end{array}$ & $\begin{array}{l}-49 \\
-47 \\
-46 \\
-45 \\
-44\end{array}$ & $\begin{array}{l}+9.1 \\
+4.1 \\
+5.4 \\
+5.4 \\
+5.2\end{array}$ & $\begin{array}{l}1371.2 \\
1444.8 \\
1459.0 \\
1518.0 \\
1572.1\end{array}$ & $\begin{array}{l}-23 \\
-16 \\
-15 \\
-9 \\
-4\end{array}$ & $\begin{array}{l}-1.7 \\
-3.9 \\
-0.6 \\
-6.5 \\
-6.6\end{array}$ \\
\hline $\begin{array}{l}762.7 \\
796.8 \\
827.3 \\
882.6 \\
937.1\end{array}$ & $\begin{array}{r}-79 \\
-76 \\
-73 \\
-68 \\
-63\end{array}$ & $\begin{array}{l}-3.7 \\
-2.1 \\
-4.1 \\
-3.0 \\
-2.6\end{array}$ & $\begin{array}{l}1158.7 \\
1181.2 \\
1193.0 \\
1204.3 \\
1227.0\end{array}$ & $\begin{array}{l}-43 \\
-41 \\
-40 \\
-39 \\
-37\end{array}$ & $\begin{array}{l}+2.4 \\
+3.2 \\
+4.2 \\
+4.7 \\
+5.7\end{array}$ & $\begin{array}{l}1584.7 \\
1770.7 \\
1781.0 \\
1909.7 \\
1927.9\end{array}$ & $\begin{array}{l}-3 \\
+14 \\
+15 \\
+26 \\
+28\end{array}$ & $\begin{array}{l}-4.8 \\
-2.9 \\
-3.5 \\
+6.1 \\
+2.7\end{array}$ \\
\hline
\end{tabular}




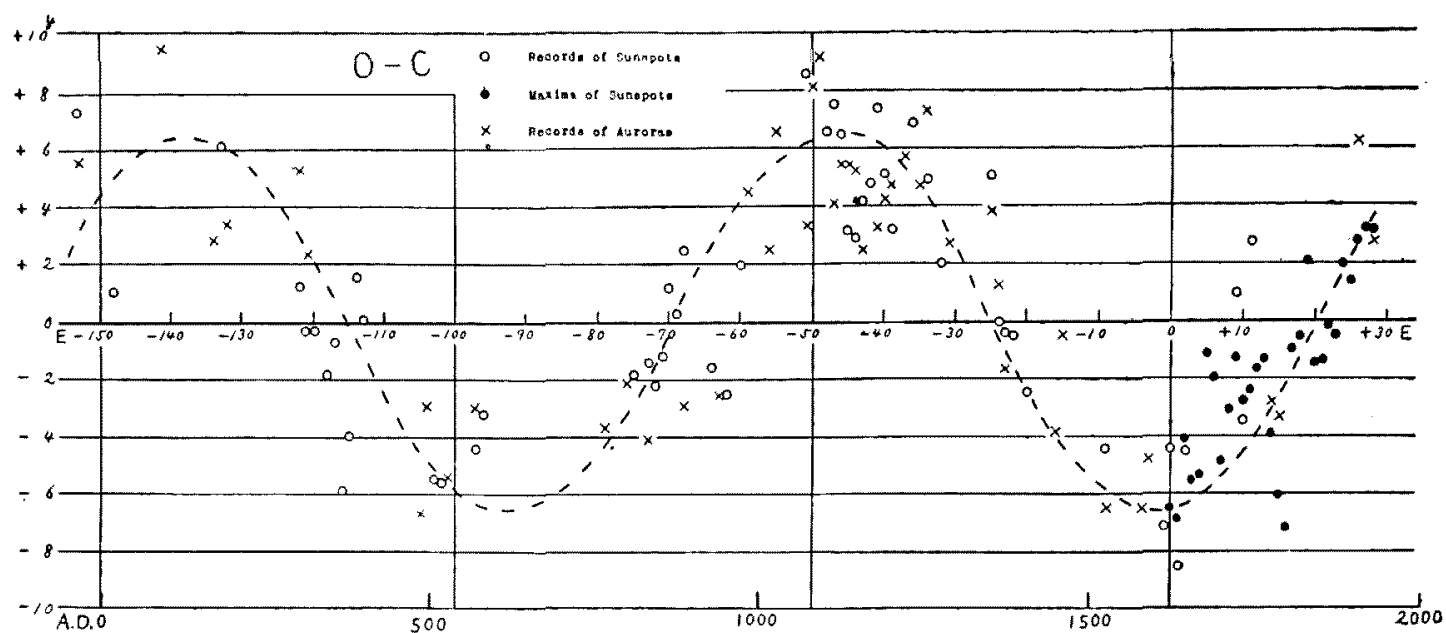

The result obtained in this way, for the epoch of sunspot maximum within past 2000 years, is

$$
\mathrm{M}=1622.0+10.83 \mathrm{E}+6.5 \sin \left(4^{\circ} .0 \mathrm{E}+280^{\circ}\right) \text {. }
$$

According to this formula, the period of solar activity is expressed by,

$$
\mathrm{P}=10.83+0.45 \cos \left(4^{\circ} .0 \mathrm{E}+280^{\circ}\right),
$$

of which the maximum and minimum values are respectively,

11.28 and 10.38 years,

and the period of variation is 975 years. 